\title{
Cation exchange HPLC analysis of desmosines in elastin hydrolysates
}

\author{
Joanna Perla-Kaján • Agnieszka Gryszczyńska • \\ Sebastian Mielcarek • Hieronim Jakubowski
}

Received: 25 February 2011 /Revised: 18 July 2011 /Accepted: 17 August 2011 / Published online: 2 September 2011

(C) The Author(s) 2011. This article is published with open access at Springerlink.com

\begin{abstract}
Desmosine crosslinks are responsible for the elastic properties of connective tissues in lungs and cardiovascular system and are often compromised in disease states. We developed a new, fast, and simple cation exchange HPLC assay for the analysis of desmosine and isodesmosine in animal elastin. The method was validated by determining linearity, accuracy, precision, and desmosines stability and was applied to measure levels of desmosines in porcine and murine organs. The detection and quantification limits were 2 and 4 pmol, respectively. The run-time was $8 \mathrm{~min}$. Our cation exchange column does not separate desmosine and isodesmosine, but their level can be quantified from absorbance at different wavelengths. Using this assay, we found that desmosines levels were significantly lower in elastin isolated from various organs of immunodeficient severe combined immunodeficiency mice compared with wild-type animals. We also found that desmosines levels were lower in lung elastin isolated from
\end{abstract}

\footnotetext{
J. Perła-Kaján $(\triangle) \cdot$ H. Jakubowski

Department of Biochemistry and Biotechnology,

Poznań University of Life Sciences,

60-637 Poznań, Poland

e-mail: kajan@up.poznan.pl
}

A. Gryszczyńska • S. Mielcarek

Quality Control of Medicinal Products and Dietary Supplements

Department, Institute of Natural Fibres and Medicinal Plants,

61-707 Poznań, Poland

\section{H. Jakubowski $(\bowtie)$}

Department of Microbiology and Molecular Genetics,

UMDNJ-New Jersey Medical School,

Newark, NJ 07101, USA

e-mail: jakubows@umdnj.edu hyperhomocysteinemic $P c f t^{-/-}$mice deficient in intestinal folate transport compared with wild-type $P c f t^{+/+}$animals.

Keywords Cation exchange HPLC - Desmosine · Isodesmosine · Elastin · Homocysteine - Pcft mouse · SCID mouse

$\begin{array}{ll}\text { Abbreviations } \\ \text { Des } & \text { Desmosine } \\ \text { Hcy } & \text { Homocysteine } \\ \text { isoDes } & \text { Isodesmosine } \\ \text { Pcft } & \text { Proton-coupled folate transporter } \\ \text { PBS } & \text { Phosphate-buffered saline } \\ \text { SCID } & \text { Severe combined immunodeficiency } \\ \text { TFA } & \text { Trifluoroacetic acid }\end{array}$

\section{Introduction}

Desmosine (Des) and its isomer isodesmosine (isoDes), major crosslinks in elastin, play an important role in the physiological function of elastic fibers. They are formed from four lysine residues, which after oxidative deamination catalyzed by lysyl oxidase, condense to a pyridinum ring-containing structure. Des and isoDes, owning to their uniqueness in mammalian elastin, are widely used as biomarkers for a range of human diseases, such as chronic obstructive pulmonary disease, acute lung injury, aneurysm, cystic fibrosis, pseudoxanthoma elasticum, bronchiectasis, and atherosclerosis [1]. During the last 30 years, a number of desmosines assays have been developed for tissues and biological fluids. Commonly used approaches include amino acid analysis, immunological methods (radioimmunoassay 
[2-4], ELISA [5-8]), column chromatography [9], and capillary electrophoresis [10-14]. A comprehensive summary of strategies for the detection of desmosines was published in 2007 by Viglio et al. [15]. Since that time, further progress has been made to lower limits of detection and increase robustness. Boutin et al. [16] developed a high-sensitivity method based on a nanoflow liquid chromatography tandem mass spectrometry with multiple reaction monitoring. Detection limit achieved by this approach is $0.1 \mathrm{ng}$ free desmosine/mL. Most recently, Shiraishi et al. [9] employed ultra-performance liquid chromatography coupled to tandem mass spectrometry that allows quantification of human urinary desmosines from 1 to $250 \mathrm{pmol} / \mathrm{mL}$.

The most widely used assay employs HPLC on a reversed phase C18 column [1, 16-19], originally developed in 1981 by Faris et al. [17] for desmosines quantification in animal tissues. To increase the sensitivity of detection, desmosines are derivatized with trinitrophenyl [20], napthalenedialdehyde/cyanide [21], dansylchloride [22], or phenylisothiocyanate [23, 24].

In the present study, we describe a new, simple, and fast HPLC method for the determination of desmosines in animal tissues. The assay utilizes a cation exchange polysulfoethyl aspartamide column. Because their charges are identical, Des and isoDes did not separate from each other and eluted at the same time. The differences in their ultraviolet absorption spectra were used to quantify Des and isoDes levels. The method is validated by determining linearity, accuracy, precision, and Des stability and is applied to measure levels of desmosines in pig and mice organs.

\section{Experimental section}

Reagents and proteins

Des and isoDes were from Elastin Products Company and LGC Standards, respectively. Human aorta elastin (soluble), $\mathrm{NaCl}$, and trifluoroacetic acid (TFA) were from Sigma-Aldrich.

Animals

The following animals were used for the preparation of elastin: five male C57BL6/J mice (1 year old; The Jackson Laboratory, Bar Harbor, ME) [25], three male CBySmn. $\mathrm{CB} 17-\mathrm{Prkdc}^{\text {scid }} / \mathrm{J}$ mice (severe combined immunodeficiency (SCID); The Jackson Laboratory; one 6 months old and two 10 months old) [26], five proton-coupled foliate transporterdeficient $\left(\mathrm{Pcft}^{-/}\right)$and six $P c f t^{+/+}$mice (6 and 8 weeks old) [27], and one male pig ( 7 days old; Złotnicka White from Rolniczy Zakład Doświadczalny Złotniki, Poland).
Preparation of elastin from animal tissues

Elastin was prepared by the hot alkali method [28] from lung, heart, kidney, and liver of five male C57BL 6/J mice [25]; heart, lung, liver, kidney, spleen, testicle, and brain of

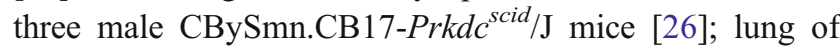
five $P c f t^{-/-}$and six $P c f t^{+/+}$mice [27]; and from lung, heart, aorta, kidney, liver, and skin of one male pig. Briefly, 1.9$3.7 \mathrm{~g}$ of frozen pig tissue was pulverized in liquid nitrogen using a mortar and pestle pre-chilled to $-80{ }^{\circ} \mathrm{C}$. The pulverized tissue was extracted by sonication in 10 volumes of phosphate-buffered saline (PBS) on ice (six strokes of $10 \mathrm{~s}$ at $70 \mathrm{~W}$ power). After centrifugation at $26,000 \times \mathrm{g}$ for $20 \mathrm{~min}$, pellet was washed with PBS, defatted with 2:1 chloroform/methanol $(v / v)$, and hydrolyzed with 10 volumes of $1 \mathrm{~N} \mathrm{NaOH}$ on a boiling water bath for $45 \mathrm{~min}$. The $\mathrm{NaOH}$-resistant pellet of elastin was washed once with 10 volumes of $1 \mathrm{~N} \mathrm{NaOH}$ and twice with 10 volumes of water, suspended in water, aliquoted, and dried by centrifugation under vacuum.

The elastin preparation procedure for mouse organs was modified due to the small amount of material $(0.02-0.10 \mathrm{~g}$ from Pcft-deficient mice [27] and 0.04-0.54 g from other mice). Mouse tissues were homogenized and washed with 10 volumes of PBS. The defatting step was omitted and tissue was boiled with shaking in $1 \mathrm{~mL} \mathrm{NaOH}$. After centrifugation $(18,000 \times g, 30 \mathrm{~min})$, pellet was washed once with $1 \mathrm{~mL} \mathrm{NaOH}$ and twice with $1 \mathrm{~mL}$ water.

Preparation of desmosines from animal elastin

Elastin from animal tissues was hydrolyzed with $6 \mathrm{M} \mathrm{HCl}$ in 1-mL Wheaton Gold Band glass ampoules (sealed under vacuum) for 16-22 h. The hydrolysates were dried, dissolved in $60-\mu \mathrm{L}$ water, clarified by microcentrifugation, and $20-\mu \mathrm{L}$ aliquots were subjected to HPLC.

HPLC analysis, detection, and quantification

HPLC analyses were carried out on an Agilent 1,100 series system, equipped with binary pump, autosampler, column thermostat, and photodiode array UV detector. Chromatograms were analyzed with Agilent ChemStation software. Samples $(20 \mu \mathrm{L})$ were injected into a cation exchange polysulfoethyl aspartamide column $(35 \times 2 \mathrm{~mm}, 5 \mu \mathrm{m}$, $300 \AA$; PolyLC, Wilmington, DE) at $24{ }^{\circ} \mathrm{C}$. The flow rate was $0.36 \mathrm{~mL} / \mathrm{min}$. The column was eluted with a linear gradient from $0 \%$ to $52.5 \% 1 \mathrm{M} \mathrm{NaCl}, 0.1 \%$ TFA for $6.1 \mathrm{~min}$, followed by $52.5 \% 1 \mathrm{M} \mathrm{NaCl}, 0.1 \%$ TFA (from 6.1 to $7.1 \mathrm{~min}$ ), and re-equilibration with $0.1 \%$ TFA (from 7.1 to 8 or $12 \mathrm{~min}$ ). A run-time for each sample was $8 \mathrm{~min}$. The detection was by monitoring UV absorption at $\lambda=240 \mathrm{~nm}$ and $\lambda=268 \mathrm{~nm}$. 
Areas of the peaks recorded at 240 and $268 \mathrm{~nm}$ was used for the quantification of Des and Des + isoDes, respectively. Each analyte possesses a molar absorption coefficient which can be deduced from its calibration line and Lambert-Beer law. By using the coefficient, absorbance A can be expressed as:

$$
\begin{aligned}
A(268 \mathrm{~nm}) & =A(\text { Des })+A(\text { isoDes }) \\
& =k 1 * c(\text { Des })+k 2 * c(\text { isoDes }),
\end{aligned}
$$

where $c$ is concentration, $k 1$ and $k 2$ are molar absorption coefficients of Des and isoDes, respectively.

Then, $c($ isoDes $)=[A(268 \mathrm{~nm})-k 1 * c($ Des $)] / k 2$.

With the known $k 1, k 2$, and $c$ (Des) deduced at $240 \mathrm{~nm}$, the $c$ (isoDes) can thus be calculated.

In other words, after the $c$ (Des) is obtained from the calibration curve at $240 \mathrm{~nm}$, the absorbance of the Des at $268 \mathrm{~nm}$ can be calculated and the value subtracted from the total absorbance of both components at $268 \mathrm{~nm}$. As a result, concentration of isoDes can be estimated in samples.

\section{Calibration and linearity}

Authentic Des or isoDes, dissolved in water $(10 \mathrm{mM})$ and stored in aliquots at $-20{ }^{\circ} \mathrm{C}$, were used as standards. A calibration line was generated for each series of assays. Three to 11 dilutions of Des and isoDes from 2 pmol to $5 \mathrm{nmol}$ were prepared to generate a calibration line. Each concentration was run in duplicate or triplicate. The corresponding peak areas at 240 and $268 \mathrm{~nm}$ were plotted against the amount of Des and isoDes (in pmol). A linear regression was used to calculate levels of Des and Des + isoDes in analyzed samples.

\section{Accuracy}

Accuracy of the method was determined by recovery experiments. Human elastin samples were spiked with five different amounts of Des (from 125 to 2,000 pmol) prior to acid hydrolysis. Three human elastin samples without Des as well as standard Des solutions were processed in parallel. Each sample was analyzed in duplicate. From the data, percentage recovery $(\%$ recovery $=[(a-b) / c] \times 100$, where, $a$ is elastin spiked with Des, $b$ is elastin, $c$ is the amount of Des standard added), and the relative standard deviation (RSD) of recovery was calculated.

\section{Precision}

Precision of the method was determined from within-run and between-run variation studies. For the within-run variation, two to three injections of standard and sample solutions were made and RSD values were calculated. For the between-run variation, four to ten injections of standard sample solutions were made and the RSDs calculated.

\section{Stability of desmosines}

Freeze-thaw stability and short-term temperature stability tests were performed on standard Des and isoDes. For freeze and thaw stability, two aliquots of 125,500 , and 2,000 pmol standards were stored at $-20{ }^{\circ} \mathrm{C}$ for $24 \mathrm{~h}$ and thawed unassisted at room temperature. When completely thawed, the samples were kept frozen for at least $24 \mathrm{~h}$ under the same conditions. The freeze-thaw cycle was repeated two more times, and HPLC measurement was performed on the third cycle. For short-term stability, two aliquots of each of the above concentrations were kept at room temperature for $20 \mathrm{~h}$ then kept at $-20{ }^{\circ} \mathrm{C}$ until analysis.

\section{Results and discussion}

\section{Cation exchange HPLC of des/isoDes}

Our desmosines assay employs a polysulfoethyl aspartamide cation exchange column that is routinely used for the quantification of homocysteine (Hcy), Hcy-thiolactone, and $N$-Hcy-protein in biological samples [29-31]. Because of the presence of five positive charges in their molecules (four on Lys amino groups and one on the nitrogen in the pyridinum ring), Des and isoDes are bound to the polysulfoethyl aspartamide column much more strongly than any other amino acid and, under conditions used for HPLC separation, elute at the same time. Possible minor elastin crosslinks, e.g., neodesmosine, oxodesmosine, isooxodesmosine, and allodesmosine, contain two to four positive charges [32] are thus expected to be eluted earlier from the polysulfoethyl aspartamide column, which separates according to the number of positive charges in the analyte structure. Desmosines were eluted with a salt gradient and detected by UV absorbance. The elution time for desmosines was approximately $5.6 \mathrm{~min}$, and the run was completed in $8 \mathrm{~min}$ (Fig. 1(A, B)). This run-time is shorter than runtimes for other methods, for example, 12 (with elution time of $8.95 \mathrm{~min}$ ) [33] and $15 \mathrm{~min}$ (with elution time of $6.5 \mathrm{~min}$ ) [9]. The identity of desmosines was confirmed by UV spectrum and comigration with Des and isoDes standards. Des has three UV maxima (at 205, 235, and $268 \mathrm{~nm}$ ), whereas isoDes has two maxima (at 205 and $280 \mathrm{~nm}$ ) (Fig. 2) [34]. Thus, Des and isoDes can be quantified in mixtures by monitoring UV absorption at $\lambda=240 \mathrm{~nm}$ (Des) and $\lambda=268 \mathrm{~nm}$ (Des + isoDes). 


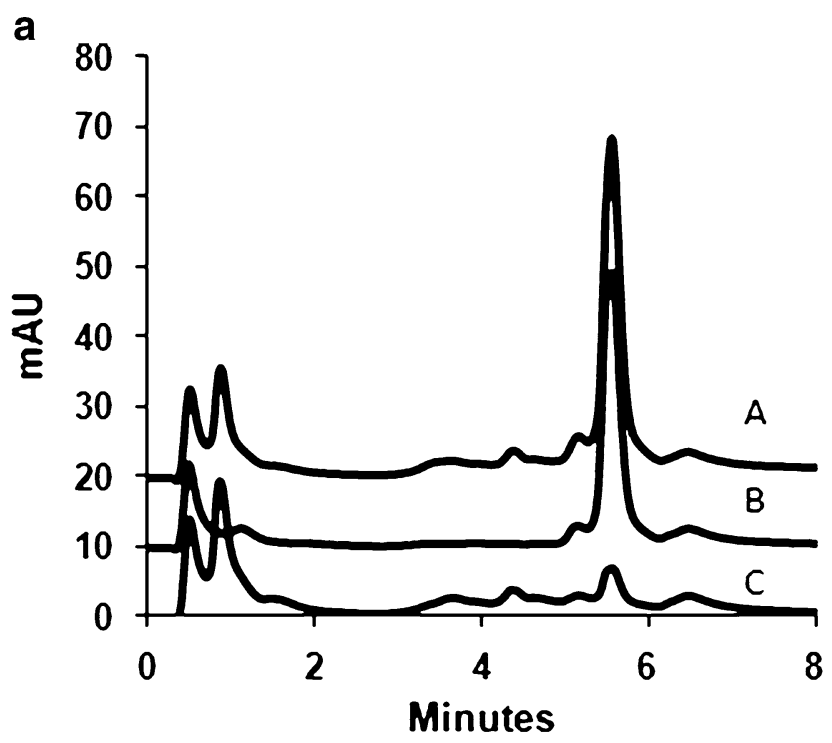

b

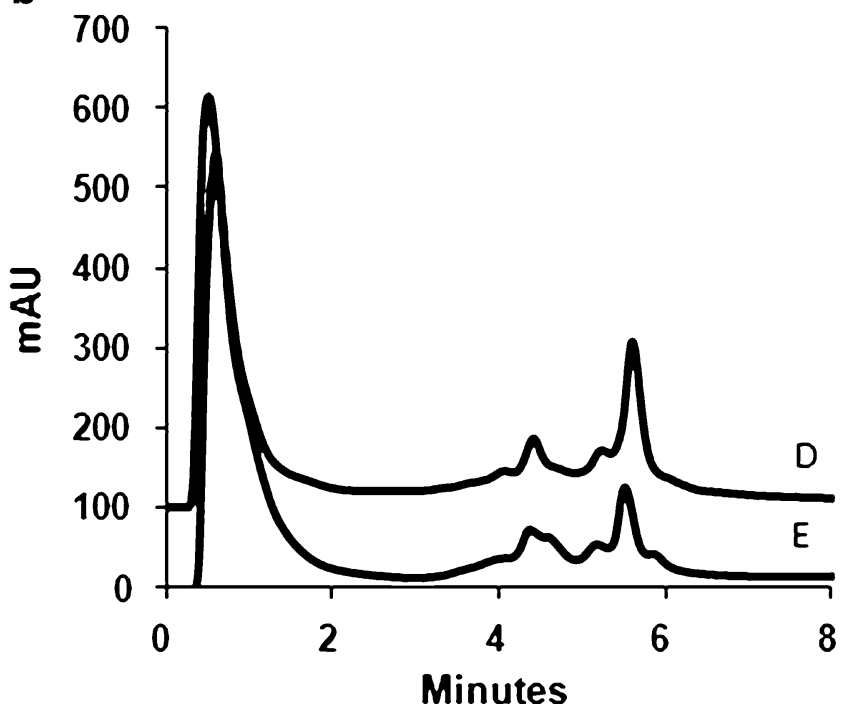

Fig. 1 Cation exchange HPLC determination of desmosines. Traces obtained with the following samples are shown: $(A)$ acid hydrolysate of human aorta soluble elastin spiked with Des standard (100 pmol), (B) Des standard (100 pmol), (C) acid hydrolysate of human aorta soluble elastin, $(D)$ acid hydrolysate of lung elastin from wild-type C57BL 6/J mice, and $(E)$ acid hydrolysate of mice lung elastin spiked with Des + isoDes 1:1 mixture (100 pmol each). Detection was at $\lambda=$ $268 \mathrm{~nm}$ and $\lambda=240 \mathrm{~nm}$. For clarity, only traces recorded at $\lambda=268 \mathrm{~nm}$ are shown and the traces are shifted by 10 or $100 \mathrm{mAU}$. Des and isoDes elute at $5.6 \mathrm{~min}$

This method was used to measure the level of desmosines in hydrolysate of soluble elastin from human aorta (Sigma). Figure 1(A) shows chromatograms of the elastin hydrolysate (trace C), the hydrolysate spiked with Des standard (trace A), and Des standard alone (trace B). The average molar ratio of desmosines to elastin for soluble elastin from human aorta calculated from three independent experiments was $1.80 \pm 0.18$ (corresponsding to 2.7 desmo-

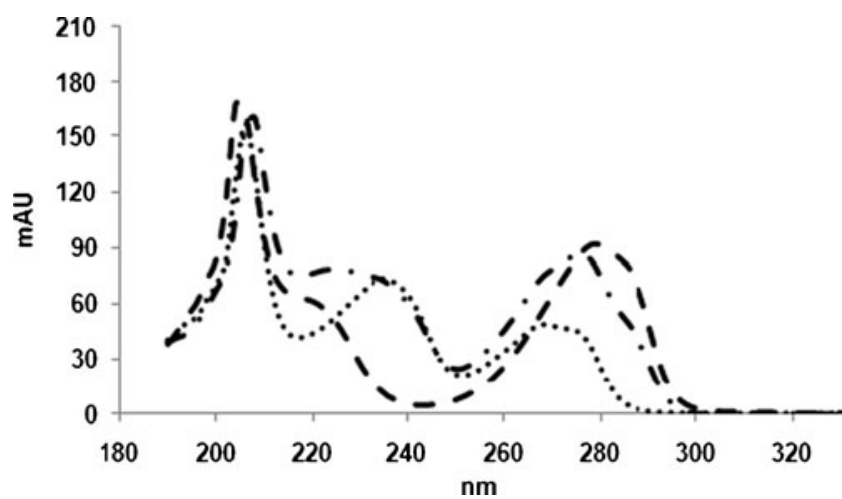

Fig. 2 UV spectra of Des and isoDes. Dotted line, Des; broken line, isoDes; dotted/broken line, spectrum of the 5.6 min peak from the HPLC analysis of pig lung elastin

sines/1,000 amino acid residues). This value is within the range of Des + isoDes content in elastin reported in the literature, e.g., levels of Des + isoDes elastin from human aorta presented by John and Thomas were 2.1-3.3/1,000 amino acid residues [35].

The level of desmosines was also measured in hydrolysates of elastin isolated from animal tissues. Figure 1(B) shows chromatograms of mouse lung elastin hydrolysate spiked with Des + isoDes 1:1 mixture (trace D) and elastin hydrolysate without addition of standards (trace E).

\section{Calibration, linearity, accuracy, and precision}

Des and isoDes standards were dissolved in water and subjected to cation exchange HPLC. As shown in Fig. 3, at $\lambda=240 \mathrm{~nm}$, absorption from Des is much greater than from isoDes, so this wavelength was used to calculate the level of Des. At $\lambda=268 \mathrm{~nm}$, absorption of Des and isoDes are identical. The calibration plots, obtained by plotting peak areas at 240 (Fig. 3A) and $268 \mathrm{~nm}$ (Fig. 3B) vs. the quantity of Des and isoDes were linear from 4 to 2,000 pmol Des $\left(r^{2}=1.0000\right.$ and 0.9995 , respectively). The limit of detection and quantification was 2 and 4 pmol, respectively. Percentage recovery was $108.8 \pm 1.2$. The within-run and between-run variations were $5.4 \%$ and $15.6 \%$, respectively.

Stability of desmosine

Short-term stability at room temperature and the stability following three freeze-thaw cycles were assessed using two aliquots of three concentrations of standard Des and isoDes. Each aliquot was run in duplicate. No significant reduction in the amount of Des and isoDes was observed following $20 \mathrm{~h}$ storage at room temperature $(102.7 \pm 5.2 \%$ and $104.0 \pm 2.6 \%$ recovery, respectively) or after three freeze-thaw cycles $(98.0 \pm 1.9 \%$ and $102.9 \pm 4.9 \%$ recovery, respectively). 

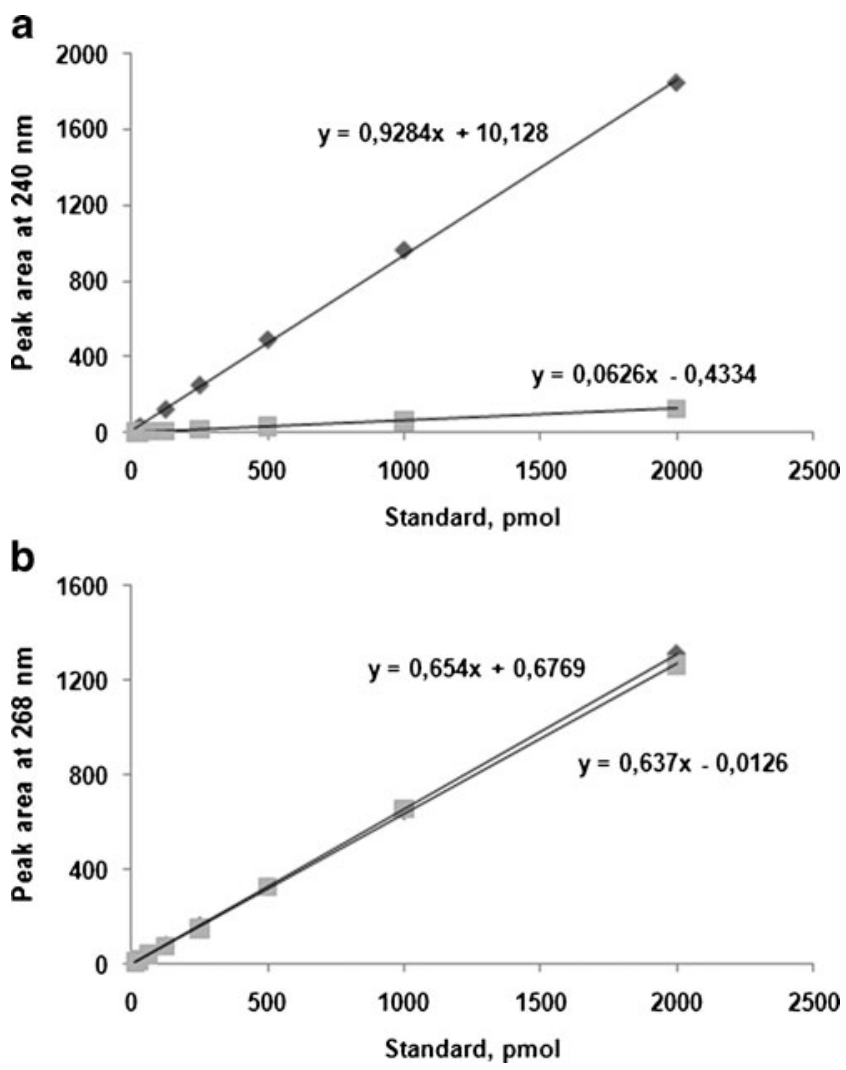

Fig. 3 Calibration lines for Des (diamonds) and isoDes (squares) standards at $\lambda=240 \mathrm{~nm}$ (a) and $\lambda=268 \mathrm{~nm}$ (b)

Desmosines levels in elastin from animal organs

Insoluble elastin was prepared from animal tissues using a hot alkali method that affords a product with an amino acid composition matching the composition expected for elastin. The yield, quantified by weighing the dry insoluble material obtained after the hot alkali procedure, was from 3.6 to $41.9 \mathrm{mg}$ elastin/g tissue. Desmosines were liberated from elastin by hydrolysis with $6 \mathrm{~N} \mathrm{HCl}$ and quantified by cation
Table 2 Desmosines levels in elastin isolated from lungs of Pcftdeficient and wild-type $P c f t^{+/+}$mice

\begin{tabular}{lcc}
\hline Genotype $(n)$ & $\begin{array}{l}\text { Desmosine } \\
\text { (pmol/mg lung) }\end{array}$ & $\begin{array}{l}\text { Desmosine + isodesmosine } \\
\text { (pmol/mg lung) }\end{array}$ \\
\hline$P c f t^{-/-}(4)$ & $36.0 \pm 18.6^{*}$ & $35.8 \pm 21.0 * *$ \\
$P c f t^{+/+}(5)$ & $52.7 \pm 20.4$ & $57.8 \pm 21.3$ \\
$* P=0.12 ; * * P=0.08$ vs. control mice &
\end{tabular}

exchange HPLC on a polysulfoethyl aspartamide column. A major retained peak eluting at approximately $5.6 \mathrm{~min}$ had a UV spectrum characteristic of a mixture of Des and isoDes (Fig. 2).

Desmosines levels in mouse elastin, expressed as pmol per $\mathrm{mg}$ tissue, are shown in Table 1. In the wild-type C57BL 6/J mice, the highest levels of Des and Des + isoDes were found in lung and heart elastin and the lowest in liver elastin (Table 1).

In the pig, the highest levels of Des were found in aorta (76.4 pmol/mg tissue) and lung (17.3 pmol/mg tissue) elastin and the lowest in liver elastin ( $0.8 \mathrm{pmol} / \mathrm{mg}$ tissue). Pig skin, kidney, and heart contained intermediate levels of desmosines, 8.3, 8.2, and $3.6 \mathrm{pmol} / \mathrm{mg}$ tissue, respectively. Des + isoDes had similar distribution in swine tissues. The highest levels of Des + isoDes were found in aorta (128.0 $\mathrm{pmol} / \mathrm{mg}$ tissue) and lung (32.0 pmol/mg tissue) elastin and the lowest in liver elastin ( $0.9 \mathrm{pmol} / \mathrm{mg}$ tissue). Pig skin, kidney, and heart contained intermediate levels of desmosines, $16.2,15.2$, and $6.6 \mathrm{pmol} / \mathrm{mg}$ tissue, respectively. These levels are consistent with levels of desmosines previously reported for animal elastin [36].

Immunodeficiency prevents desmosine crosslinks formation in mouse elastin

We assayed desmosines levels in elastin isolated from various organs of immunodeficient SCID mice [26]. Similar to wild-type mice, CBySmn.CB17-Prkdc scid/J mice had the

Table 1 Desmosines levels in elastin isolated from different mouse organs

\begin{tabular}{|c|c|c|c|c|}
\hline \multirow[t]{2}{*}{ Organ (weight, g) } & \multicolumn{2}{|c|}{ Desmosine (pmol/mg tissue) } & \multicolumn{2}{|c|}{ Desmosine + isodesmosine $(\mathrm{pmol} / \mathrm{mg}$ tissue $)$} \\
\hline & C57BL 6/J mice & CBySmn.CB17-Prkdc $c^{\text {scid }} / \mathrm{J}$ mice & C57BL 6/J mice & CBySmn.CB17-Prkdc scid/J mice \\
\hline Lung $(0.15 \pm 0.02)$ & $67.8 \pm 9.5$ & $49.3 \pm 8.3^{*}$ & $108.9 \pm 24.0$ & $62.7 \pm 9.1^{*}$ \\
\hline Heart $(0.16 \pm 0.06)$ & $7.5 \pm 2.7$ & $2.1 \pm 1.7^{*}$ & $13.9 \pm 5.4$ & $4.9 \pm 3.3^{*}$ \\
\hline Kidney $(0.41 \pm 0.05)$ & $1.7 \pm 0.3$ & $1.0 \pm 0.2$ & $3.1 \pm 0.5$ & $2.2 \pm 0.5^{*}$ \\
\hline Liver $(0.42 \pm 0.07)$ & $1.2 \pm 0.3$ & $1.6 \pm 2.2$ & $1.8 \pm 0.2$ & $0.56 \pm 0.09^{*}$ \\
\hline Spleen $(0.05 \pm 0.01)$ & & $14.6 \pm 0.01$ & & $21.1 \pm 4.5$ \\
\hline Testicle $(0.14 \pm 0.01)$ & & $6.5 \pm 3.5$ & & $7.4 \pm 2.4$ \\
\hline Brain $(0.24 \pm 0.01)$ & & $1.0 \pm 1.8$ & & $1.2 \pm 1.9$ \\
\hline
\end{tabular}

Each value is an average of assays with two to five animals ${ }^{*} P=0.0007-0.035$, significantly different from control mice 
highest levels of desmosines in lung elastin, and the lowest in liver elastin (Table 1). However, Des levels were significantly lower in lung and heart but not in kidney

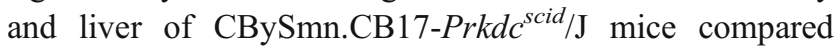
with wild-type C57BL 6/J mice. Des + isoDes levels were significantly lower in elastin isolated from lung, heart, kidney, and liver elastin of mutant mice compared with control animals (Table 1). These findings indicate that deficiency in elastin crosslinking is a novel phenotype contributing to the pathology of immunodeficient SCID mice.

Hyperhomocysteinemia prevents desmosine crosslink formation in mouse lung elastin

We also assayed desmosines levels in lung elastin isolated from Pcft-deficient mice that have 20-fold higher plasma Hcy compared with $P c f t^{+/+}$animals [27]. We found that Des and Des + isoDes levels in lung elastin from $P c f t^{-1-}$ mice tended to be lower (1.5- and 1.6-fold, respectively) compared with wild-type $P c f t^{+/+}$animals, although the difference did not reach statistical significance $(P=0.12$ and 0.08 , respectively, Table 2).

Desmosines from $\mathrm{Pcft}^{-/-}$and $P c f t^{+/+}$had essentially identical UV spectra and elastin levels were similar in $P c f t^{-/}$and $P c f t^{+/+}$mice. Taken together, these results suggest that hyperhomocysteinemia causes deficiency in elastin crosslinking in the mouse lung. These findings are reminiscent of previous findings in rat, where vitamin B6 deficiency [37] or intraperitoneal injections of Hcy + Met [38] elevated plasma Hcy levels and decreased elastin desmosines levels.

\section{Conclusions}

We have developed a new cation exchange HPLC assay for the determination of desmosines in animal elastin. Our assay is highly specific (desmosines elute as a major UVabsorbing peak on chromatograms), fast (separation is achieved in $8 \mathrm{~min}$, a much shorter time than previously reported for other methods), inexpensive (requires only two reagents for separation), and reliable. The utility of this new assay was demonstrated for the analysis of human, mouse, and pig elastin. We could measure desmosine crosslinks in elastin hydrolysates from as little as $20 \mathrm{mg}$ of mice lung. Our new assay's sensitivity of 4 pmol is sufficient for analyses of animal tissues. For analyses of limited amounts of biological material, other techniques, such as, HPLC or UPLC coupled to mass spectrometry are available $[9,16,33]$. Using our new assay, we found that desmosines levels in mouse lung elastin were decreased in immunodeficient SCID and hyperhomocysteinemic $P \mathrm{Cft}^{-/-}$ mice compared with wild-type animals. This method should help to elucidate the role of desmosine crosslinks in health and disease.

Acknowledgments This work was supported in part by grants from the Ministry of Science and Higher Education, Poland (NN 401 230634) and the American Heart Association (0855919D). We thank Ewa Pruszyńska-Oszmałek (Department of Animal Physiology and Biochemistry, Poznań University of Life Sciences) and Ryszard Słomski (Institute of Human Genetics, Polish Academy of Sciences, Poznań, Poland) for kindly providing mouse and pig organs. We thank Jarosław Zimny for assistance in HPLC analyses in the initial stage of the method development. We also thank anonymous reviewers for their constructive comments.

Open Access This article is distributed under the terms of the Creative Commons Attribution Noncommercial License which permits any noncommercial use, distribution, and reproduction in any medium, provided the original author(s) and source are credited.

\section{References}

1. Yamaguchi Y, Haginaka J, Kunitomo M, Yasuda H, Bando Y (1987) High-performance liquid-chromatographic determination of desmosine and isodesmosine in tissues and its application to studies of alteration of elastin induced by atherosclerosis. J Chromatogr-Biomed Appl 422:53-59

2. Harel S, Janoff A, Yu S, Hurewitz A, Bergofsky E (1980) Desmosine radioimmunoassay for measuring elastin degradation in vivo. Am Rev Respir Dis 122:769-773

3. King GS, Mohan VS, Starcher BC (1980) Radioimmunoassay for desmosine. Connect Tissue Res 7:263-267

4. Starcher B, Scott M (1992) Fractionation of urine to allow desmosine analysis by radioimmunoassay. Ann Clin Biochem 29(Pt 1):72-78

5. Gunja-Smith Z (1985) An enzyme-linked immunosorbent assay to quantitate the elastin crosslink desmosine in tissue and urine samples. Anal Biochem 147:258-264

6. Laurent P, Magne L, De Palmas J, Bignon J, Jaurand M (1988) Quantitation of elastin in human urine and rat pleural mesothelial cell matrix by a sensitive avidin-biotin ELISA for desmosine. J Immunol Methods 107:1-11

7. Watanabe T, Ishimori K, Verplanke A, Matsuki H, Kasuga H (1989) An enzyme-linked immunosorbent assay (ELISA) for the quantitation of urinary desmosine. Tokai J Exp Clin Med 14:347-356

8. Osakabe T, Seyama Y, Yamashita S (1995) Comparison of ELISA and HPLC for the determination of desmosine or isodesmosine in aortic tissue elastin. J Clin Lab Anal 9:293-296

9. Shiraishi K, Matsuzaki K, Matsumoto A, Hashimoto Y, Iba K (2010) Development of a robust LC-MS/MS method for determination of desmosine and isodesmosine in human urine. J Oleo Sci 59:431-439

10. Annovazzi L, Viglio S, Perani E, Luisetti M, Baraniuk J, Casado B, Cetta G, Iadarola P (2004) Capillary electrophoresis with laserinduced fluorescence detection as a novel sensitive approach for the analysis of desmosines in real samples. Electrophoresis 25:683-691

11. Annovazzi L, Viglio S, Gheduzzi D, Pasquali-Ronchetti I, Zanone C, Cetta G, Iadarola P (2004) High levels of desmosines in urine and plasma of patients with pseudoxanthoma elasticum. Eur J Clin Invest 34:156-164

12. Boschetto P, Quintavalle S, Zeni E, Leprotti S, Potena A, Ballerin L, Papi A, Palladini G, Luisetti M, Annovazzi L, Iadarola P, De Rosa E, Fabbri L, Mapp C (2006) Association between markers of emphysema and more severe chronic obstructive pulmonary disease. Thorax 61:1037-1042 
13. Stolk J, Veldhuisen B, Annovazzi L, Zanone C, Versteeg E, van Kuppevelt T, Berden J, Nieuwenhuizen W, Iadarola P, Luisetti M (2005) Short-term variability of biomarkers of proteinase activity in patients with emphysema associated with type $Z$ alpha-1antitrypsin deficiency. Respir Res 6:47

14. Giummelly P, Botton B, Friot R, Primaputra D, Atkinson J (1995) Measurement of desmosine and isodesmosine by capillary zone electrophoresis. J Chromatogr A 710:357-360

15. Viglio S, Annovazzi L, Luisetti M, Stolk J, Casado B, Iadarola P (2007) Progress in the methodological strategies for the detection in real samples of desmosine and isodesmosine, two biological markers of elastin degradation. J Sep Sci 30:202-213

16. Boutin M, Berthelette C, Gervais F, Scholand M, Hoidal J, Leppert M, Bateman K, Thibault P (2009) High-sensitivity nanoLC-MS/MS analysis of urinary desmosine and isodesmosine. Anal Chem 81:1881-1887

17. Faris B, Ferrera R, Glembourtt M, Mogayzel PJ, Crombie G, Franzblau C (1981) Rapid quantitation of desmosine content in tissue hydrolysates by high-performance liquid chromatography. Anal Biochem 114:71-74

18. Covault H, Lubrano T, Dietz A, Rubinstein H (1982) Liquidchromatographic measurement of elastin. Clin Chem 28:14651468

19. Chen J, Takahashi M, Kushida K, Suzuki M, Suzuki K, Horiuchi K, Nagano A (2000) Direct detection of crosslinks of collagen and elastin in the hydrolysates of human yellow ligament using singlecolumn high performance liquid chromatography. Anal Biochem 278:99-105

20. Fujimoto D (1982) Aging and cross-linking in human aorta. Biochem Biophys Res Commun 109:1264-1269

21. Lunte SM, Mohabbat T, Wong OS, Kuwana T (1989) Determination of desmosine, isodesmosine, and other amino-acids by liquidchromatography with electrochemical detection following precolumn derivatization with naphthalenedialdehyde cyanide. Anal Biochem 178:202-207

22. Guida E, Codini M, Palmerini CA, Fini C, Lucarelli C, Floridi A (1990) Development and validation of a high-performance liquidchromatographic method for the determination of desmosines in tissues. J Chromatogr 507:51-57

23. Hanis T, Deyl Z, Struzinsky R, Miksik I (1991) Separation of elastin cross-links as phenylisothiocyanate derivatives. J Chromatogr 553:93-99

24. Salomoni M, Muda M, Zuccato E, Mussini E (1991) Highperformance liquid chromatographic determination of desmosine and isodesmosine after phenylisothiocyanate derivatization. J Chromatogr 572:312-316

25. Black B, Croom J, Eisen E, Petro A, Edwards C, Surwit R (1998) Differential effects of fat and sucrose on body composition in $\mathrm{A} / \mathrm{J}$ and C57BL/6 mice. Metabolism 47:1354-1359

26. Bosma M, Schuler W, Bosma G (1988) The scid mouse mutant. Curr Top Microbiol Immunol 137:197-202

27. Jakubowski H, Perla-Kajan J, Finnell RH, Cabrera RM, Wang H, Gupta S, Kruger WD, Kraus JP, Shih DM (2009) Genetic or nutritional disorders in homocysteine or folate metabolism increase protein $\mathrm{N}$-homocysteinylation in mice. FASEB J 23:1721-1727

28. Mecham R (2008) Methods in elastic tissue biology: elastin isolation and purification. Methods 45:32-41

29. Jakubowski H (2002) The determination of homocysteine-thiolactone in biological samples. Anal Biochem 308:112-119

30. Chwatko G, Jakubowski H (2005) The determination of homocysteine-thiolactone in human plasma. Anal Biochem 337:271-277

31. Jakubowski H (2008) New method for the determination of protein N-linked homocysteine. Anal Biochem 380:257-261

32. Watanabe M, Sawai T (1999) Alteration of cross-linking amino acids of elastin in human aorta in association with dissecting aneurysm: analysis using high performance liquid chromatography. Tohoku J Exp Med 187:291-303

33. Ma S, Lin Y, Turino G (2007) Measurements of desmosine and isodesmosine by mass spectrometry in COPD. Chest 131:1363-1371

34. Thomas J, Elsden DF, Partridge SM (1963) Partial structure of two major degradation products from the cross-linkages in elastin. Nature 200:651-652

35. John R, Thomas J (1972) Chemical compositions of elastins isolated from aortas and pulmonary tissues of humans of different ages. Biochem J 127:261-269

36. Powell JT, Whitney PL (1980) Postnatal development of rat lung. Changes in lung lectin, elastin, acetylcholinesterase and other enzymes. Biochem J 188:1-8

37. Myers BA, Dubick MA, Reynolds RD, Rucker RB (1985) Effect of vitamin B-6 (pyridoxine) deficiency on lung elastin cross-linking in perinatal and weanling rat pups. Biochem $\mathrm{J}$ 229:153-160

38. Griffiths R, Tudball N, Thomas J (1976) Effect of induced elevated plasma levels of homocystine and methionine in rats on collagen and elastin structures. Connect Tissue Res 4:101-106 